\title{
ASSESSMENT OF QUALITY STABILITY OF COMPOSITE FLOURS PRODUCED BY DAR ES SALAAM SMES
}

\author{
Leonard M.P. Rweyemamu \\ Department of Chemical and Mining Engineering \\ College of Engineering and Technology \\ University of Dar es Salaam, P. O. BOX 35131, Dar es Salaam, \\ Tanzania \\ leonard.rweyemamu@udsm.ac.tz; leo_rwey@uccmail.co.tz
}

\begin{abstract}
A study was conducted to assess quality stability of cereal flours processed by food processing SMEs in Dar es Salaam. This product is obtained by mixing various cereal grains and is considered as of higher nutritional values in Tanzania. The shelf-life was predicted by determining water activity $\left(a_{w}\right)$ and moisture content $(M C)$ levels and plotting the water sorption isotherms (MSI). Ninety per cent of investigated samples $(N=78)$ were found packaged in the materials of various quality conditions. It was found that the packaging materials mostly used is plastic films (63\%), paper packets/bags (26\%), hard papers (3\%), plastic jars (1\%) and combination of paper packets/boards inserted with plastic film (7\%). Water sorption isotherms were plotted for single and multiple ingredient products. The highest levels of $a_{w}$ were observed for products in paper bags with $0.63\left(a_{w}\right)$ and $0.13 \mathrm{MC}$ ( $\mathrm{kg}$ water $/ \mathrm{kg}$ solids). Plastic films and jars had intermediate levels at $0.52\left(a_{w}\right)$ and $0.042 \mathrm{MC}$ ( $\mathrm{kg}$ water $/ \mathrm{kg}$ solids), and combined paper packets/boards with plastic films had lowest levels at $0.43\left(a_{w}\right)$ and $0.038 \mathrm{MC}(\mathrm{kg}$ water $/ \mathrm{kg}$ solids) exhibiting highest stability of products packaged in these materials. Relative humidity and temperature at sampling locations ranged from 80 to $94 \%$ and 30 to $34^{\circ} \mathrm{C}$, respectively. Multiple ingredient products showed the lowest $a_{w}$ and MC levels, whereas single ingredient flours possessed higher $a_{w}$ and MC values. Generally, the package system comprising paper board (or hard paper/box) and plastic bag (plastic film) was the most stable followed by plastic films, and paper bag by far.
\end{abstract}

Keywords: Food packaging, composite flour, shelf-life, water activity, water sorption isotherms

\section{INTRODUCTION}

No one legume or cereal can provide adequate amounts of all nutrients to meet the nutritional requirements of a person (FAO, 1995). With that understanding, there is a big move by small and medium scale food processing entrepreneurs in Tanzania to produce mixes or blends of legumes and cereals as a diet for overall improvement of human nutrition (Dendy, 1993). These blends, which are technically referred to as "composite flours" (Ohimain, 2014; Noorfarahzilah et al., 2014), they are good sources of energy, iron, calcium, vitamins and proteins, and they are mostly used for making porridges (Dendy, 1993; Moreno-Álvarez et al., 2009).
Ingredients used include maize, rice, peanuts, soybeans, finger millet, sorghum, pearl millet, sardines and Moringa leaves (Jeremiah, 2008). Processing steps include, sorting, cleaning, washing, milling and packaging. These methods are still undeveloped and therefore the quality of products is characterised by high variability.

The range of typical values of proximate composition for composite flours by Dar es Salaam SMEs is given in Table 1, whereas the mineral composition is given in Table 2 (Jeremiah, 2008). 
Table 1: Proximate composition of composite flour by DSM SMEs [g/100 g]

\begin{tabular}{|l|c|c|c|c|c|c|c|}
\hline & Moisture & Protein & Ash & Fat & Fibre & Carbohydrates & $\begin{array}{c}\text { Energy } \\
{[\mathrm{kcal} / 100 \mathrm{~g}]}\end{array}$ \\
\hline Minimum & 4.88 & 15.79 & 1.15 & 4.64 & 1.19 & 37.4 & 414 \\
\hline Maximum & 14.13 & 34.09 & 6.03 & 26.08 & 7.08 & 74.89 & 506.28 \\
\hline
\end{tabular}

Table 2: Mineral contents of composite flour by DSM SMEs [mg/100 g]

\begin{tabular}{|c|c|c|c|c|c|c|c|c|c|}
\hline & $\mathrm{Ca}$ & $\mathrm{K}$ & $\mathrm{Na}$ & $\mathrm{Mg}$ & $\mathrm{Cu}$ & $\mathrm{Zn}$ & $\mathrm{Fe}$ & $\mathrm{Cr}$ & $\mathrm{Mn}$ \\
\hline Minimum & 63.52 & 120.96 & 27.82 & 43.41 & 3.75 & 1.69 & 2.95 & 1.38 & 1.64 \\
\hline Maximum & 399.92 & 616.59 & 228.29 & 210.26 & 5.67 & 6.25 & 8.64 & 3.68 & 12.14 \\
\hline
\end{tabular}

Temperature, moisture content and water activity $\left(\mathrm{a}_{\mathrm{w}}\right)$ are the most important factors which affect the rate of food deterioration reactions. Water activity is a key factor in microbial growth, enzymatic and nonenzymatic reactions, physical and structural changes, toxin production, and nutrient, aroma and flavour decomposition (Barbosa-Canovas et al., 1996). Controlling $\mathrm{a}_{\mathrm{w}}$ is the basis for preservation of dry and intermediate moisture foods (Valentas, 1997).

Packaging is one of key unit operations in food processing and preservation. It performs five major functions, namely; product containment, preservation and quality, presentation and convenience, protection, and providing storage history (Jatindra, 2014). Factors that need to be considered in choosing the best suitable packaging form and material for any particular product include the product characteristics, processing considerations, shelf-life required and overall cost (Valentas, 1997; Barbosa-Canovas et al., 1996). This study was conducted to assess effect of packaging materials on water activity of composite flours produced by food processing SMEs in Dar es Salaam. Also, the study aimed at assessing the effect of ingredients on quality stability of the product.

\section{MATERIALS AND METHODS}

The samples, which were not more than six months from date of manufacture, were collected from organizations involved in supporting SMEs, namely, Small Industries Development Organization (SIDO), the University of Dar es Salaam Technology Development and Transfer Centre (TDTC), supermarkets, shops, trade exhibitions, and from producers at their production premises.

The samples were categorised according to the contents of ingredients and type of packaging materials as shown in Table 3 . All samples were analysed "as received".

Relative humidity levels at the points of sample collection were recorded by using a Hygrometer in every location where samples were collected. All experiments were conducted in the laboratories of Chemical and Mining Engineering department at the College of Engineering and Technology University of Dar es Salaam. A water activity meter (AcquaLab LITE by Decagon Devices Inc., USA) was used to measure water activity. The moisture content was determined by oven drying according to AOAC (1990) method number 945.39 A, in which a sample was dried to constant weight at $105^{\circ} \mathrm{C}$. 
Table 3: Collected and investigated samples from Dar es Salaam SMEs

\begin{tabular}{|c|c|c|c|c|c|c|c|c|c|c|c|c|c|c|c|}
\hline & $\begin{array}{r}\text { Finger } \\
\text { millet }\end{array}$ & Sorghum & Maize & Wheat & Peanut & Soybean & Rice & \begin{tabular}{|l|} 
Pearl millet \\
\end{tabular} & $\begin{array}{c}\text { Moringa } \\
\text { leaves }\end{array}$ & Sardines & Legume & $\begin{array}{c}\text { Germinated } \\
\text { cereal }\end{array}$ & $\begin{array}{c}\text { Anti- } \\
\text { oxidants }\end{array}$ & \begin{tabular}{|l|} 
Components \\
\end{tabular} & Package type \\
\hline & & & & & & & & & & & & & & & \multirow{6}{*}{ Paper bag } \\
\hline $\mathrm{sbl}$ & $\checkmark$ & & & & & & & & & & & & & 1 & \\
\hline $\mathrm{sb} 2$ & & $\checkmark$ & & & & & & & & & & & & 1 & \\
\hline $\mathrm{sb} 3$ & & $\checkmark$ & & & & & & & & & & & & 1 & \\
\hline $\mathrm{sb} 4$ & $\checkmark$ & & & & & & & & & & & & & 1 & \\
\hline $\mathrm{sb} 5$ & $\checkmark$ & & & & & & & & & & & & & 1 & \\
\hline $\mathrm{spl}$ & $\checkmark$ & & & & & & & & & & & & & 1 & \multirow{5}{*}{ Plastic bag } \\
\hline $\mathrm{sp} 2$ & $\checkmark$ & & & & & & & & & & & & & 1 & \\
\hline sp3 & $\checkmark$ & & & & & & & & & & & & & 1 & \\
\hline sp4 & & $\checkmark$ & & & & & & & & & & & & 1 & \\
\hline $\mathrm{sp} 5$ & & $\checkmark$ & & & & & & & & & & & & 1 & \\
\hline sbdp & $\checkmark$ & & & & & & & & & & & & & 1 & $\begin{array}{c}\text { Paper board + } \\
\text { Plastic bag }\end{array}$ \\
\hline $\mathrm{mb} 1$ & $\checkmark$ & & $\checkmark$ & $\checkmark$ & $\checkmark$ & $\checkmark$ & & & & & & & & 5 & \multirow{6}{*}{ Paper bag } \\
\hline $\mathrm{mb} 2$ & $\checkmark$ & & $\checkmark$ & & $\checkmark$ & $\checkmark$ & $\checkmark$ & & & & & & & 5 & \\
\hline $\mathrm{mb} 3$ & $\checkmark$ & $\checkmark$ & $\checkmark$ & & $\checkmark$ & $\checkmark$ & $\checkmark$ & $\checkmark$ & & & & & & 7 & \\
\hline $\mathrm{mb} 4$ & & & $\checkmark$ & & & & $\checkmark$ & & $\checkmark$ & & & & & 3 & \\
\hline $\mathrm{mb} 5$ & . & & $\checkmark$ & & $\checkmark$ & $\checkmark$ & $\checkmark$ & & & $\checkmark$ & & & & 5 & \\
\hline mb6 & $\checkmark$ & $\checkmark$ & & & & $\checkmark$ & & $\checkmark$ & & & & & & 4 & \\
\hline $\mathrm{mpl}$ & $\checkmark$ & & $\checkmark$ & & $\checkmark$ & $\checkmark$ & $\checkmark$ & & & & & & & 5 & \multirow{5}{*}{ Plastic bag } \\
\hline $\mathrm{mp} 2$ & $\checkmark$ & & $\checkmark$ & & $\checkmark$ & $\checkmark$ & $\checkmark$ & & & & & & & 5 & \\
\hline mp3 & $\checkmark$ & & $\checkmark$ & $\checkmark$ & $\checkmark$ & & $\checkmark$ & $\checkmark$ & & & & & & 6 & \\
\hline $\mathrm{mp} 4$ & $\checkmark$ & & $\checkmark$ & & $\checkmark$ & $\checkmark$ & $\checkmark$ & & & & & & & 5 & \\
\hline mp5 & $\checkmark$ & & $\checkmark$ & & $\checkmark$ & $\checkmark$ & $\checkmark$ & & & & & & & 5 & \\
\hline mbdp1 & $\checkmark$ & $\checkmark$ & $\checkmark$ & & & $\checkmark$ & & & & & $\checkmark$ & $\checkmark$ & $\checkmark$ & 7 & \multirow{3}{*}{$\begin{array}{c}\text { Paper board }+ \\
\text { plastic bag }\end{array}$} \\
\hline mbdp2 & $\checkmark$ & & $\checkmark$ & $\checkmark$ & $\checkmark$ & $\checkmark$ & & & & & & & & 5 & \\
\hline Total & 18 & 7 & 12 & 3 & 10 & 11 & 9 & 3 & 1 & 1 & 1 & 1 & 1 & 78 & \\
\hline
\end{tabular}

\section{RESULTS AND DISCUSSION}

\section{Identification of Powdered Food}

Products Manufactured by SMEs

Seventy eight packaged products $(\mathrm{N}=78)$ were collected during the survey. They were categorized as finger millet flour, sorghum flour, composite flour, soy meal and soy drink. The major ingredients used were identified as maize, rice, finger millet, sorghum, groundnuts, pearl millet, soybeans, sardines, sweet potatoes and Moringa oleifera leaves. They were further categorized as single and multiple ingredients, depending on the number of ingredients in the blends.

\section{Characteristics of Packaging Materials and Storage Conditions}

The type of packaging materials used by Dar es Salaam SMEs are plastic films, paper, plastic jars, hard paper and combination of hard paper and plastic films. Most of products $(63 \%)$ were packaged in plastic films, whereas paper were at $26 \%$, and combination of hard paper with inserted plastic films were $7 \%$, hard paper (boxes) alone were $3 \%$ and plastic jars $1 \%$. The plastic films varied in thickness or fineness. The volume of packaged content ranged from 200 to 2000 grams. Packages bearing label instructions on storage conditions were $42 \%$, whereas those without instructions were $58 \%$. Relative humidity and temperature of premises where the samples were collected varied from $80 \%$ to $94 \%$ and 30 to $34^{\circ} \mathrm{C}$, respectively. $72 \%$ of products had information of expiry date, while $28 \%$ had did not show this information. Product batch numbers were showed by $18 \%$ of products. It was noted that most of those not indicating expiry dates and batch number were from micro entrepreneurs, which could be attributed to lack of basic knowledge and skills in food processing.

\section{MSI for Single Ingredient Products packaged in Different Packaging Materials}

Water sorption isotherms for the singleingredient product samples were plotted from determined $a_{w}$ and $M C$ values as indicated in Figure 1. These were for finger millet, sorghum and soybean. They 
were packaged in paper bags, plastic films, and hard paper, combined paper bags and fine plastic films, and transparent plastic (PET) jars. For finger millet and sorghum flour, the packaging materials used were found to be paper bags, plastic films and combination of hard papers and plastic films. Products packed in paper bags had the highest values of $a_{w}$ and MC. Sorghum flour showed highest $\mathrm{a}_{\mathrm{w}}$ values between 0.61 to 0.63 and $\mathrm{MC}$ of 0.127 to $0.130 \mathrm{~kg}$ water $/ \mathrm{kg}$ solids, while these values for finger millet ranged from 0.57 to 0.59 and $\mathrm{MC}$ of 0.103 to $0.120 \mathrm{~kg}$ water $/ \mathrm{kg}$ solids, respectively.

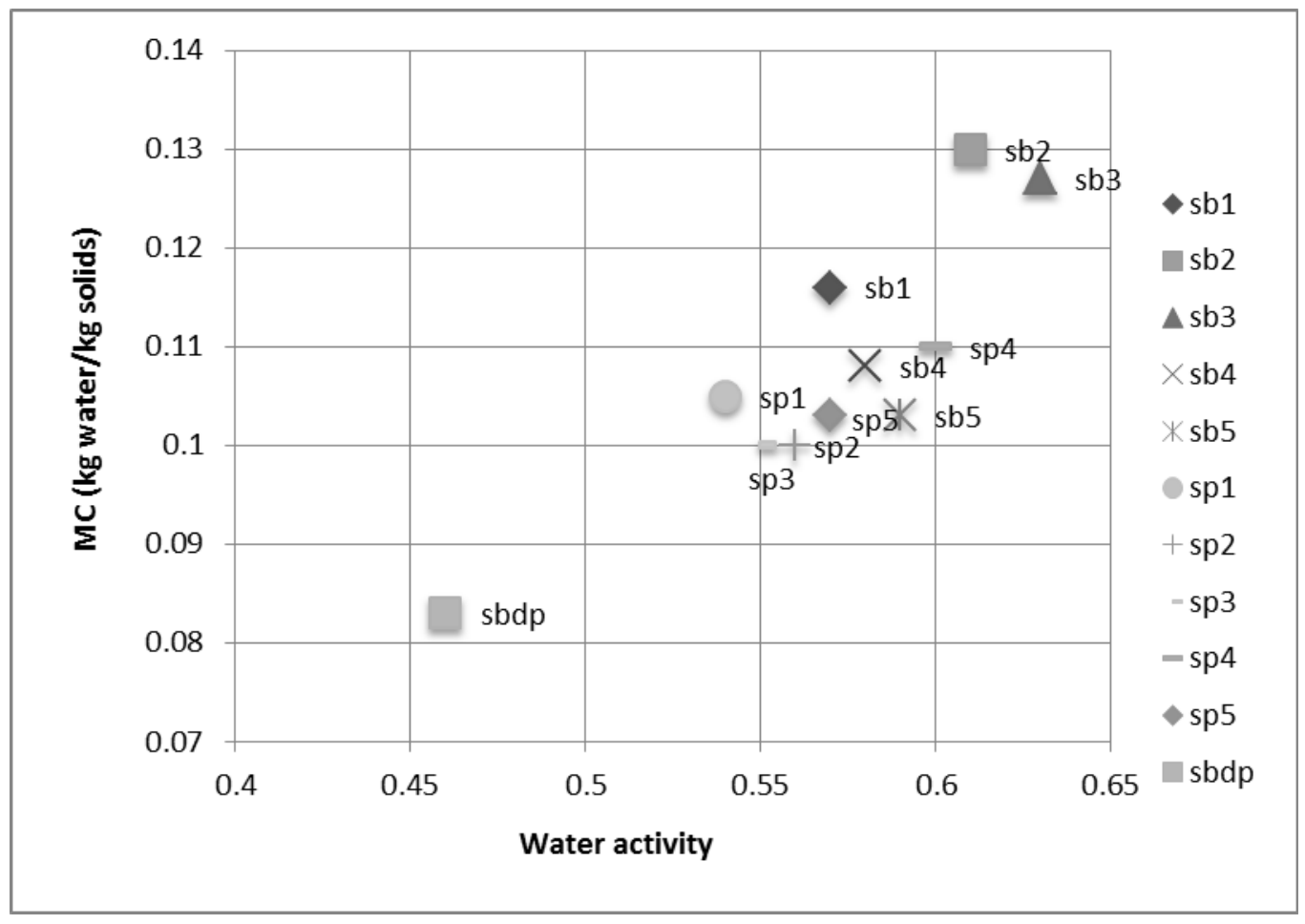

Figure 1: Water sorption isotherm for single ingredient products in different packages Key: $\mathrm{sb}=$ paper bags; $\mathrm{sp}=$ plastic films; $\mathrm{sbdp}=$ hard paper + plastic bag

Lowest values of $\mathrm{a}_{\mathrm{w}}$ and $\mathrm{MC}$ were obtained in products in plastic films. For finger millet $\mathrm{a}_{\mathrm{w}}$ values were in the range from 0.54 to 0.56 and $\mathrm{MC}$ of 0.997 to $0.105 \mathrm{~kg}$ water $/ \mathrm{kg}$ solids, while that of sorghum was again slightly higher by ranging from 0.57 to 0.6 and 0.103 to 0.110 , respectively. One product packaged in the combination of hard paper and plastic bag was analyzed and had $\mathrm{a}_{\mathrm{w}}$ and $\mathrm{MC}$ values of 0.62 and $0.109 \mathrm{~kg}$ water $/ \mathrm{kg}$ solids, respectively. This showed the highest stability, which could be attributed to double protection of the packaging type.
Absorption and desorption behavior was observed for products from the same manufacturer containing the same ingredient and packaged in similar material, for example, sb1, sb4, and sb5, which was finger millet in paper bag. The sample sb1 was on desorption side indicating that, it was losing the moisture, whereas sb5 was on the absorption side implying that the sample could be absorbing water.

The effect of packaging material on the moisture sorption behavior of the product from the same ingredient, for example, 
finger millet in plastic films (sp1, sp2, sp3), also showed the variation, which could be attributed to conditions of the air (temperature and humidity) during storage. Processing conditions could also have an effect on this variation with factors such as initial parameters of moisture before the packaging process.

\section{MSI for pure soybean flours packaged in different packaging materials}

The investigated soybean flours were packed in hard paper, plastic films, plastic jars and combination of paper box and plastic films. No paper bag was found for packaging soybean flours. The highest levels of $a_{w}$ and $M C$ were obtained in plastic films ranging from 0.46 to 0.58 and 0.042 to 0.082 , respectively. Moderate values of $\mathrm{a}_{\mathrm{w}}$ and $\mathrm{MC}$ were found in hard paper and plastic jars. Hard paper values ranged from $\mathrm{a}_{\mathrm{w}}=0.52$ to 0.54 and $\mathrm{MC}=0.048$ to 0.051 and for plastic jars from 0.52 to 0.53 and 0.042 to 0.047 , respectively. Lowest $\mathrm{a}_{\mathrm{w}}$ and $\mathrm{MC}$ levels were obtained in the combination of hard paper and plastic films and ranged from 0.43 to 0.44 and 0.038 to 0.040 , respectively (Figure 2). From figure 2 it could be observed that plastic films and combination of hard paper and plastic films are superior suitable packaging materials for soybean flours. Hard paper alone and plastic bottle indicated the tendency of moisture absorption. The water uptake behavior in plastic jars could be attributed to poor sealing of closures and air headspace. Most of locally manufactured plastic jars have had poor sealing quality.

The stability of soybean is quite different from other cereals, such as finger millet, maize or rice, which are stable at water activity of up to 0.7 compared to soybean at 0.3 to 0.4 . Since most of the products which contain soybeans as one of the ingredient were found to have water activity of 0.53 to 0.62 and moisture content of up to 0.12 ( $\mathrm{kg}$ water $/ \mathrm{kg}$ solids) this could lead to suggestion that lipid oxidation had taken place in most of the products. This oxidation might have occurred during processing, as well as during packaging operations and storage conditions.

\section{MSI for multiple ingredient products packaged in different Materials}

Products studied in this category were in paper bags, plastic films, and combination of hard paper and plastic films. These food products consist of a combination of different ingredients such as maize, rice, finger millet, sorghum, groundnuts, pearl millet, soybeans and sardine fish. The products in paper bags were found with highest values of $\mathrm{a}_{\mathrm{w}}$ and $\mathrm{MC}$, irrespective of the ingredients used, and ranged from $\mathrm{a}_{\mathrm{w}}=0.53$ to 0.62 , and $\mathrm{MC}=0.088$ to 0.121 . Plastic films were found to have moderate values from $\mathrm{a}_{\mathrm{w}}=0.46$ to 0.62 and $\mathrm{MC}=0.083$ to 0.113 . The lowest values were obtained in combination of hard paper and plastic films and ranging from $\mathrm{a}_{\mathrm{w}}=0.41$ to 0.45 , and 0.075 to 0.080 MC (Figure 3). 


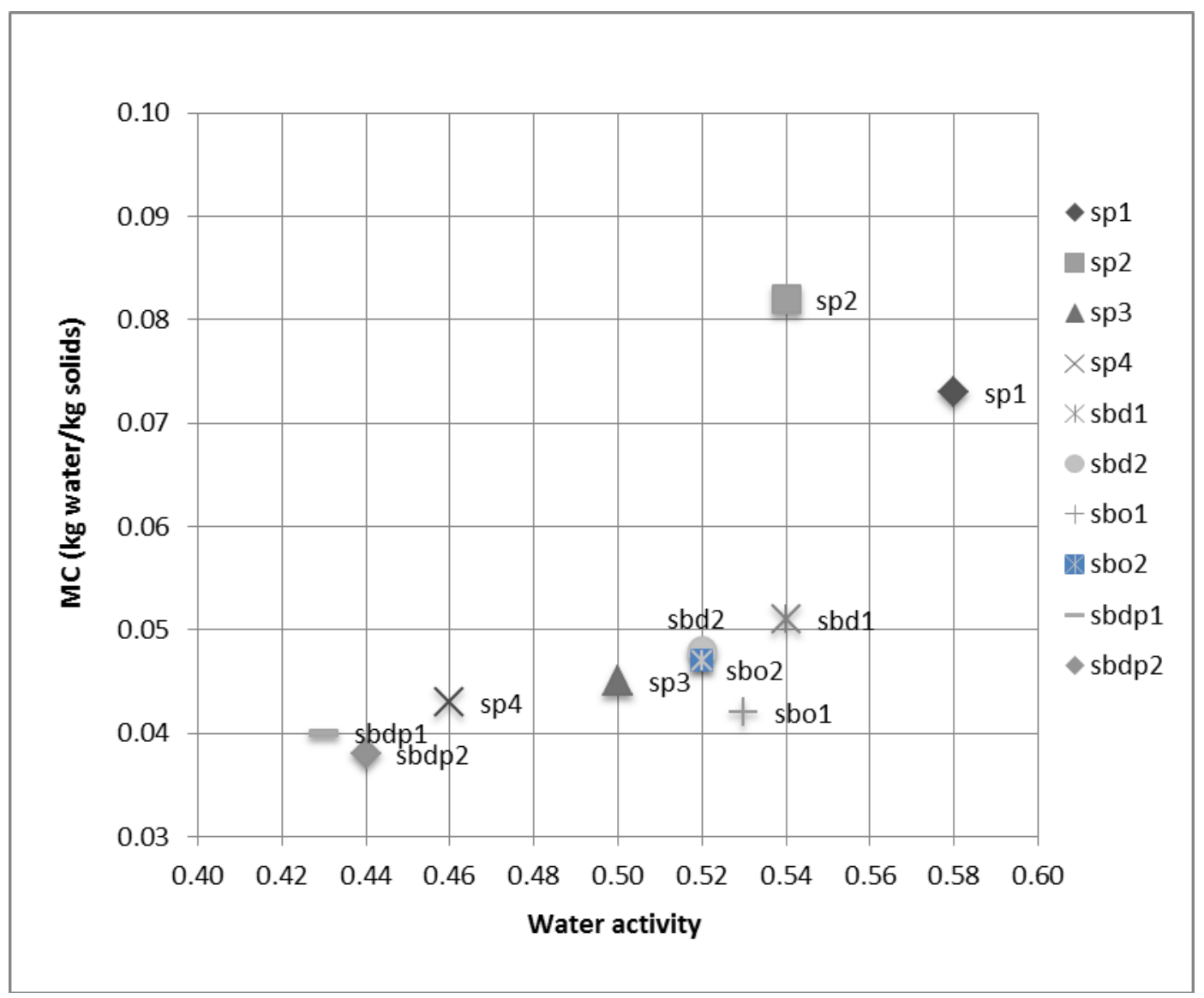

Figure 2: Water sorption isotherm for pure soybean flours in different packages Key: $\mathrm{sp}=$ plastic films; sbd $=$ hard paper; sbo = plastic jars; sbdp =hard paper + plastic bag

The combination of hard paper and plastic film (mbdp1 and mbdp2) showed to be most suitable packaging materials followed by plastic films ( $\mathrm{mp} 5$ and $\mathrm{mp} 6$ ). The variation of sample location on moisture sorption may be attributed to differences in the physical structure, type of ingredients, chemical composition and extent of water binding. From Figure 3, it can be observed that the investigated samples could form the sigmoid shape of the MSI absorption curve.

\section{Determination of factors affecting stability of powdered food products by SMES}

\section{Effects of the type of packaging material} By plotting all investigated samples in one MSI diagram three distinct zones for packaging materials could be observed. These zones could be identified as the zone for paper bags, plastic films, and paper-board + plastic film combination zone (Figure 4). From Figure 4 it could be observed that the paper bag is on the higher $\mathrm{a}_{\mathrm{w}}$ and $\mathrm{MC}$ zone being followed by plastic films and finally double protection packaging combination of paperboard + plastic films.

The higher levels of $\mathrm{a}_{\mathrm{w}}$ and MC for food products packaged in paper bags and hard papers could be attributed micro pores and cracks in the package walls and sealed areas and in closures, and also permeation through the package, which may permit microbe penetration into the package (Valentas, 1997). The material for paper bag is made from cellulose, a natural fiber which is hygroscopic, it absorbs moisture and therefore its dimensional stability under changes of humidity and temperature is poor (Emblem, 2006).

The plastic films used were mostly of low density polyethylene (LDPE). The lower 
levels of $\mathrm{a}_{\mathrm{w}}$ and MC for plastic materials show the high barrier property of the materials to oppose the passage of molecules or compound to diffuse through, either flavor, aromas and components from food, or external compounds from the environment to the food. This trend was vice versa for food products in the paper bags which have the lower barrier property.

It was generally observed that most of packaging materials used had variation in their capability to withstand potential factors which cause deterioration of foods during storage, such as UV light, moisture, vapor, oxygen, and temperature changes, microbial contamination, and insects. They were also weak to withstand mechanical forces which may result in damage by impact, vibration, compression or abrasion. Except for paper bags and hard paper, the plastic materials used were mostly LDPE films, which transmits both visible and ultraviolet light to similar extent. Excessive transmission of light through these plastic materials during storage may result into loss of nutrients such as vitamins, colour and flavour.

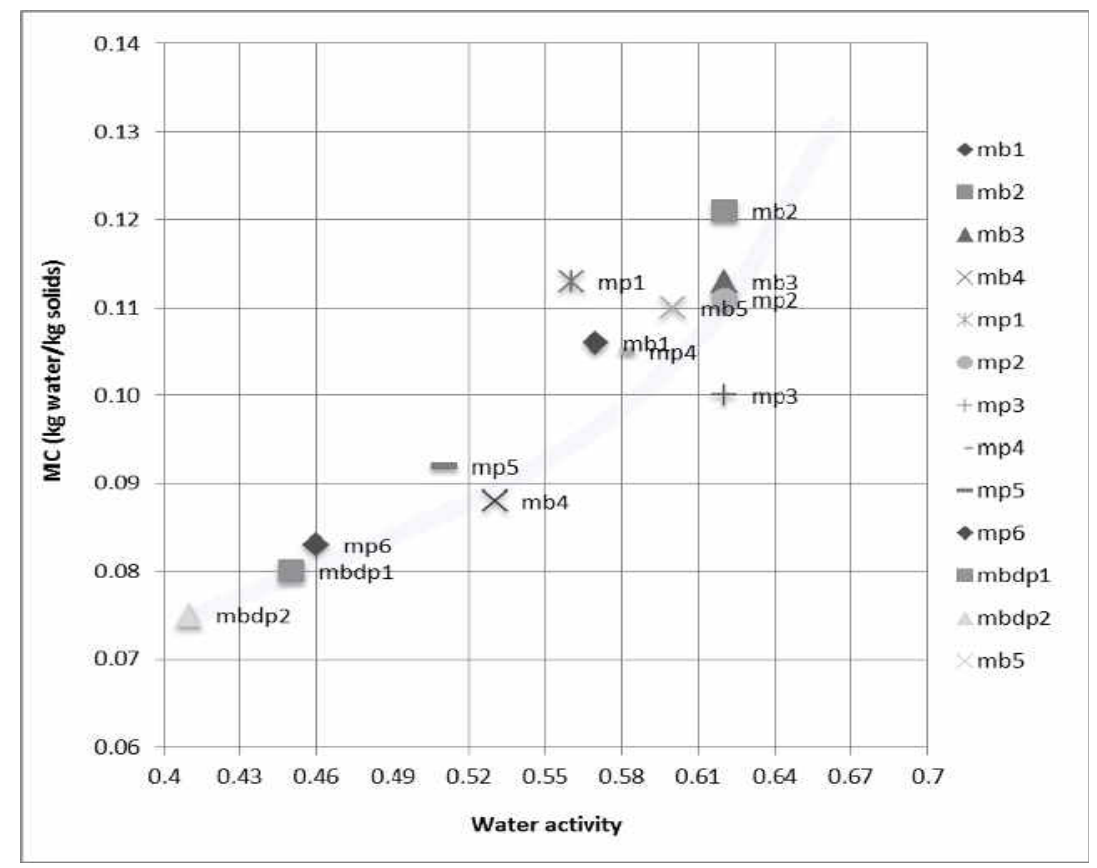

Figure 3: Water sorption isotherm for multiple ingredient flours in different packages

Key: $a=$ paper bags; $b=$ plastic films; $c=$ hard paper + plastic $b a g$

\section{Effects of blend ingredients}

Pure finger millet and sorghum flour showed higher values of $\mathrm{a}_{\mathrm{w}}$ and $\mathrm{MC}$ compared to multiple-ingredient products irrespective of the type of packaging materials used. Sorghum also showed higher levels of $\mathrm{a}_{\mathrm{w}}$ and MC. This may be attributed to the type of protein in finger millet (Pomeranz, 1991). Some of pure soybean products with $\mathrm{a}_{\mathrm{w}}$ values of 0.5 0.6 and $\mathrm{MC}$ of 0.04 to 0.08 ( $\mathrm{kg}$ water $/ \mathrm{kg}$ solids) were found to develop rancidity which was detected by taste and smell.

About $57 \%$ of the products analyzed could be categorized as intermediate moisture foods with $\mathrm{a}_{\mathrm{w}}$ levels between 0.55 to 0.65 and $\mathrm{MC}$ values from 0.10 to $0.14(\mathrm{~kg}$ water $/ \mathrm{kg}$ solids). Average $\mathrm{a}_{\mathrm{w}}$ levels were around 0.6 , where browning rate is usually at maximum. For this reason, these foods are susceptible to lose essential nutrients such as amino acids which lead to 
degradation of protein during browning. are most likely to be affected. Also, their colours, aromas and flavours

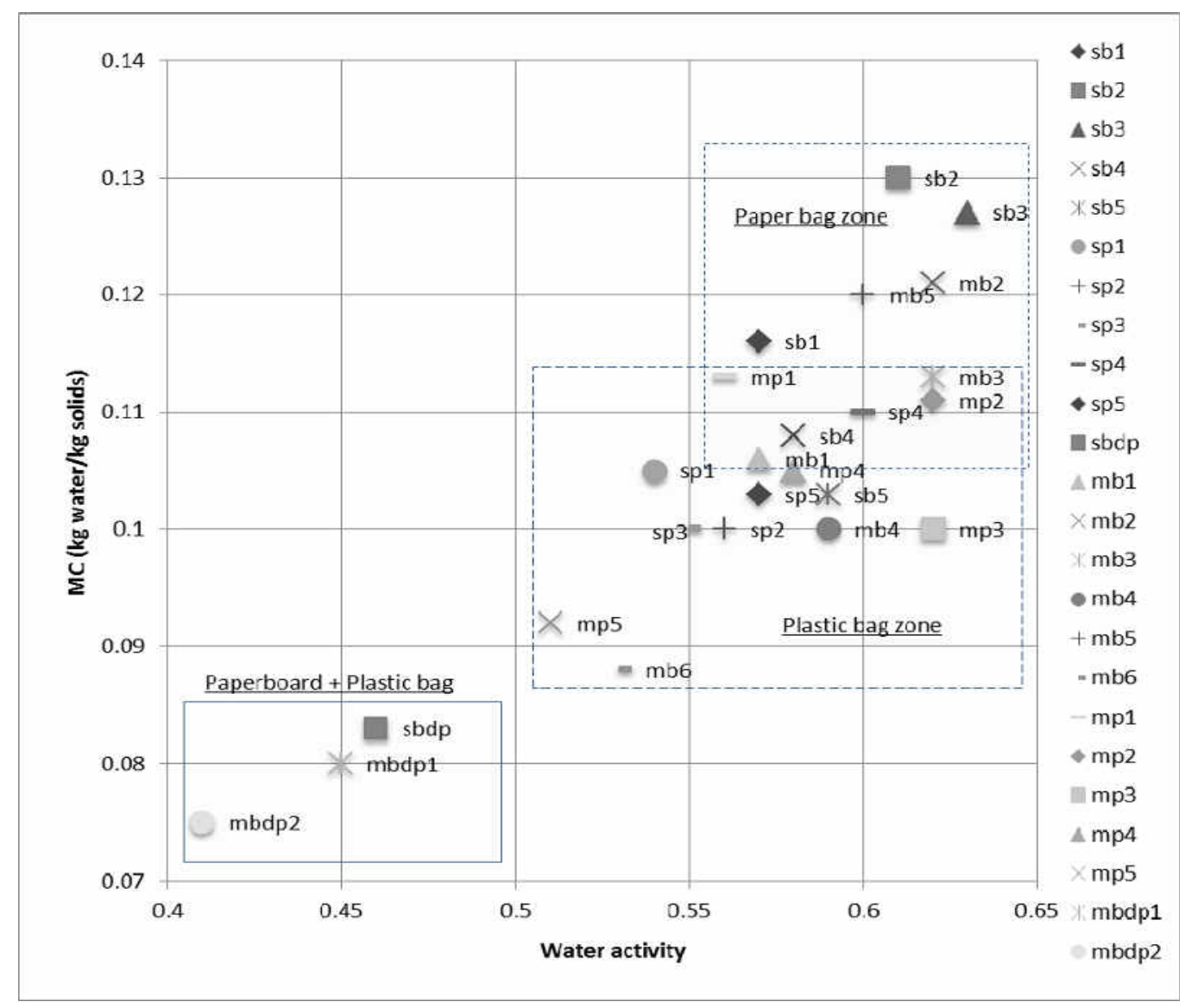

Figure 4: Water sorption isotherm for powdered products in different packages

\section{Effect of sardines on quality stability}

Products containing sardines were found to have $\mathrm{a}_{\mathrm{w}}=0.6$ and $\mathrm{MC}=0.11$ and were rotten and therefore not worth for human consumption. This could be due to initial loading of spoilage microorganisms which are mostly present in sardines, because of processing and handling conditions.

\section{Effect of Time and Relative humidity (RH) during storage}

Products which had stayed for a long time in the market were observed to have high values of water activity and moisture content which suggests that as these products continue to be exposed to the environment they absorb moisture and allow other mass transfer processes, which could be attributed to ingredients used, type of packaging materials and relative humidity in storage premises.

It was observed that most of products analyzed lie on the adsorption curve in the region for less strongly bound water layers and capillary adsorbed water on the moisture sorption isotherms. Some samples were in the region of free water condensed within the capillary structure or in the cells of a food. This is because relative humidity of surroundings for most places where products were collected was $80 \%$ and above and moisture content of most products was around $10 \%$. At these conditions adsorption is likely to occur thereby allowing movement of moisture from the environment to the food until the equilibrium relative humidity is achieved (Singh et al., 2003). Free water is 
available for microbial growth and enzyme activity and under this situation these foods are likely to be susceptible to spoilage (Barbosa-Canovas et al., 1996).

\section{CONCLUSION}

Cereal and composite flour products by SMEs are characterized by poor packaging systems which may contribute to degraded quality stability. Products with single ingredient have higher values of $\mathrm{a}_{\mathrm{w}}$ and $\mathrm{MC}$ compared to others irrespective of types of packaging materials used, the factor which could lead to low stability. Paper bags provide lowest stability in comparison to plastic films and the combination of plastic films and hard paper. Products in plastic films were found to have intermediate values of $\mathrm{a}_{\mathrm{w}}$ and $\mathrm{MC}$ irrespective of the ingredients used and the lowest values of $\mathrm{a}_{\mathrm{w}}$ and $\mathrm{MC}$ were observed for products in combined paper box and plastic films, which provides double protection. Selection of sardines needs careful consideration. Generally, the package system comprising paper board (or hard paper/box) and plastic bag (plastic film) was the most stable followed by plastic films, and paper bag by far.

\section{ACKNOWLEDGMENTS}

The author is thankful to Head, Department of Chemical and Mining Engineering, College of Engineering and Technology, University of Dar es Salaam for providing necessary facilities.

\section{REFERENCES}

Barbosa-Canovas G.V. and VegaMercado H. (1996). Dehydration of Foods. Chapman \& Hall. New York.

Dendy D.A.V. (1993). Review of composite flour technology in the context of Tanzania. A paper presented at the workshop. Sorghum and millets marketing and utilization, Arusha
Tanzania, May 3-5, 1993. r4d.dfid.gov.uk/pdf/outputs/R5128b.pd f. [Accessed 15.06.2015]

Ohimain E.I. (2014). Global Journal of Human-Social Science 14(3): 42-52.

Emblem A. (2006). Predicting packaging characteristics to improve shelf-life. The Institute of Packaging.

FAO (1995). Sorghum and millets in human nutrition. FAO Food and Nutrition Series, No. 27. ISBN 92-5103381-1.

http://www.fao.org/docrep/t0818e/T08 18E00.htm\#Contents [Accessed 15.06.2015].

Fellows P.J. (2000). Food Processing Technology- Principles and Practice, $2^{\text {nd }}$ edition. Woodhead Publishing Limited. Cambridge, England.

Jatindra K.S. (2014). Introduction to Advanced Food Process Engineering. Taylor \& Francis Group, USA.

Jeremiah J.M. (2008). Utilization of Soybeans and Moringa Oleifera as Potential Alternative Sources of Micronutrients in the Production of Micronutrients-rich Flour. University of Dar es Salaam. Tanzania.

Kilcast, D. and Subramaniam, P. (2000). The stability and shelf-life of food. Woodhead Publishing Limited. Cambridge, England.

Moreno-Álvarez M.J., Hernández R., Belén-Camacho D.R., MedinaMartínez C.A., Ojeda-Escalona C.E. and García-Pantaleón D.M. (2009). Making of bakery products using composite flours. Wheat and cactus pear (Opuntia boldinghii Britton et Rose) stems (cladodes) J. PACD, 11: 78-87.

www.jpacd.org/downloads/vol11/vo 111 8.pdf [Accessed 15.06.2015].

Noorfarahzilah M., Lee J.S., Sharifudin M.S., Mohd Fadzelly A.B. and Hasmadi M. (2014). Applications of 
composite flour in development of food products. International Food Research Journal. Available on line at http://www.ifrj.upm.edu.my

Pomeranz Y. (1991). Functional Properties of Food Components, $2^{\text {nd }}$ edition. Academic Press, Inc. New York.

Singh R.P. and Heldman D. (2003). Introduction to Food Engineering. Academic Press, London.
UNICEF TANZANIA (2010). The Children's Agenda. http://www.tenmet.org/1goaltanzani a/The $\% 20$ Children $\% 27 \mathrm{~s} \% 20$ Agenda .pdf. [Accessed 10.11.2010].

Valentas K.J., Rotstein E. and Singh R.P. (1997). Handbook of Food Engineering Practice. CRC Press. New York. 